\title{
Pharmaciana
}

Vol.10, No.3, Nov 2020, Page. 315-324

ISSN: 2088 4559; e-ISSN: 24770256

DOI: $10.12928 /$ pharmaciana.v10i3.16640

\section{Wound healing activity of Aloe vera extract spray on acute wound in male balb/c mice}

\author{
Isabella Meliawati Sikumbang, ${ }^{1,5}$, Ratih Arum Astuti², Eka Sakti Wahyuningtyas ${ }^{3,5}$, \\ Heni Lutfiyati ${ }^{1}$, Ratna Wijayatri ${ }^{1}$, Nasruddin ${ }^{* 4,5}$ \\ ${ }^{1}$ Department of Pharmacy, Faculty of Health Science, Universitas Muhammadiyah Magelang \\ Jl. Mayjend Bambang Soegeng, Mertoyudan, Magelang, Central Java, Indonesia \\ 2Department of Pharmaceutical, Faculty of Pharmacy, Universitas Ahmad Dahlan Yogyakarta \\ Jl. Prof Soepomo, Janturan, Yogyakarta, Indonesia \\ ${ }^{3}$ Department of Nursing, Faculty of Health Science, Universitas Muhammadiyah Magelang \\ Jl. Mayjend Bambang Soegeng, Mertoyudan, Magelang, Central Java, Indonesia \\ ${ }^{4}$ Department of Medical Laboratory Science, Faculty of Nursing and Health Science, Universitas \\ Muhammadiyah Semarang \\ Jl. Kedungmundu Raya No.18, Semarang, Indonesia \\ ${ }^{5}$ Research Center for Experimental Wound Healing, Universitas Muhammadiyah Magelang \\ Jl. Mayjend Bambang Soegeng, Mertoyudan, Magelang, Central Java, Indonesia
}

Submitted: 18-06-2020

Reviewed: 05-09-2020

Accepted: 04-11-2020

\begin{abstract}
Acute wounds are tissue injuries that are at risk of infection so they require good treatment and care. Aloe vera (Aloe vera $L$ ) contains glucomannan compound that are thought to be beneficial in the wound healing process. Spray preparations in the treatment of wounds can provide concentrared content, dry quickly, and easy to use. The purpose of this study was to examine the spray activity of Aloe extract as an acute wound healer in male balb/c mice. This research method is experimental research. The steps that have been carried out include maceration extraction from Aloe vera simplicia powder with $70 \%$ ethanol which was then thick extracted in freeze drying to powder extract. Aloe vera spray preparations were made with concentrations of $1 \%, 3 \%$ and $5 \%$. Balb / C mice that had made full thickness acute wounds were divided into 5 treatment groups namely positive control (PC), negative control (NC), F1, F2, and F3. Mice were treated for 14 days then the wound ratio was calculated and analyzed with one way anova test followed by Post Hoc Tukey Cramer test. The results showed that the higher of the percentage of Aloe vera extract is the higher of the wound healing activity.
\end{abstract}

Keywords: acute wound, Aloe vera, spray

\footnotetext{
*Corresponding author :

Nasruddin

Department of Medical Laboratory Science, Faculty of Nursing and Health Science

Universitas Muhammadiyah Semarang

J1. Kedungmundu Raya No.18, Semarang, Indonesia

Email: nasruddin@unimus.ac.id
} 


\section{INTRODUCTION}

Acute wounds have a rapid attack and healing is around 8-12 weeks (Hashemi et al., 2015). The results of the healing of disrupted wounds such as acute injuries which are late handling and chronic wounds in general will fail to progress to the normal wound healing stage. These wounds often enter pathological inflammatory conditions due to delayed, incomplete or uncoordinated wound healing processes. Wounds that do not heal result in high health costs incurred around 3 billion USD per year (Menke et al., 2007). Acute wound healing enclose a complex, dynamic, well-orchestrated series of events (Enoch and Leaper, 2007). Oxoferin is a topical patent drug that contains tetrachlorodecaoxide (TCDO) which can help epithelialization, induce the development of granulation tissue and stimulate the immune system (Shahbaz et al., 2017) . The use of synthetic drugs can cause adverse effects such as irritation and super-infection, namely an increase in the number of bacterial colonies in the wound when there is resistance, causing pain and sensitivity to sulfa. Patent medicines that are often used to heal wounds have a relatively high market price and are not affordable by some people. Therefore, people need new alternatives or innovations, namely utilizing medicinal plants to be used as traditional medicines that are more affordable, easy to obtain and have minimal side effects. Medicinal plants used for wound healing can help repair mechanisms in a natural way, one of these medicinal plants is Aloe vera which is made into a topical spray preparation.

Aloe vera contains prostaglandins and bradykinin hydrolysis which acts to relieve pain and inflammation. In addition, the content of the enzyme amilaze in Aloe vera removes the aloctin-A necrosal tissue which plays a role in cell division and mitosis, accelerates wound healing and produces macrophages to produce these dead tissue. Aloe vera has amino acids which play a role in producing protein, which is used for tissue growth and healing. Vitamin content including $\beta$-carotene, Vit E, Vit $\mathrm{C}$, and $\mathrm{B}$ complex play a role in cell reactions, function as antioxidants, and contain antraquinone compounds which have the ability to be antibacterial (Vázquez et al.,1996). Various research reported that ethanol extract of Aloe vera gel has a bactericidal and germicidal actions as well as an antifungal action (Itrat, 2013). Anti-microbial substances Aloe vera can prevent excessive increase in proinflammatory cytokines (TNF-a and IL-6) in the inflammatory phase which in this phase involves humoral and cellular cells in the immune response because this stage involves infection of microorganisms, and prevents Endothelial-leukocyte interactions are significant, thus accelerating the inflammatory phase (Duansak et al., 2003). Aloe vera in this study will be made into spray preparations. This study aims to determine the physical characteristics of Aloe vera extract spray preparations and test the wound healing activity of Aloe vera extract spray in vivo on male balb / c mice (Mus musculus) skin.

\section{MATERIALS AND METHODS \\ Materials}

The materials used in this study were Aloe vera that obtained from Magelang, Central Java, Aloe vera is taken from a 10-month-old plant with light green leaf and stem specifications.

\section{Methods \\ Plant determination}

Plant samples used in this study were Aloe vera plants. Determination of Aloe vera plants and male balb/c mice was carried out at the Biology Laboratory of Ahmad Dahlan University in Yogyakarta.

\section{Making Aloe vera extract powder}

Aloe vera that has been collected is sorted wet then washed with running water. Then drained and chopped into small pieces $\pm 1 \mathrm{~cm}$, roasted at a temperature of $50^{\circ} \mathrm{C}$ for 48 hours. Dry simplisia is then made into powder by blending and sifted with a 25 mesh size sieve. Simplification of the moisture 
content ( \pm 1 gram) was carried out using a moisture balance tool. Aloe vera powder was extracted using maceration method with a ratio of powder and solvent 1: 5 meaning that 1 part of the simplicia powder was dissolved in 5 parts of the solvent. Extraction was carried out using 70\% ethanol solvent and stirred for 3 hours then allowed to stand for 24 hours. The filtered filtrate is then evaporated at a water bath at $50^{\circ} \mathrm{C}$ until a thick extract is obtained. The viscous extract obtained was then pulverized using a freeze dryer to form a powder. The extract is first frozen for 24 hours. The purpose of this freezing is so that during the drying process using the freeze dryer the sublimation process can run smoothly. Samples that have been frozen for 24 hours are then dried using a freeze dryer for 72 hours with a temperature of $-15{ }^{\circ} \mathrm{C}$.

\section{Making Aloe vera spray preparations}

The spray formula can be seen in Table 1 . In the first stage, carbopol 940 is dispersed in a quantity of water until it is homogeneous. In a separate container. In the next step, a mixture of carbopol 940 with water that had previously been formed was mixed with triethanolamine. Next, into this solution, propylene glycol is added while stirring until it is homogeneous (mixture A). In a separate container Aloe vera extract was dissolved in a DMSO solution, then methyl paraben and propyl paraben were also dissolved in the mixture and homogenized until homogeneous (mixture B). The mixture $\mathrm{B}$ is added to mixture A, both are homogenized until it is completely mixed, then the mixture is ad in with aquadest and homogenized until a clear spray is obtained (Iswandana and Sihombing, 2017).

Table 1 Aloe vera extract spray formula

\begin{tabular}{llllll}
\hline \multirow{2}{*}{ Material } & \multicolumn{1}{c}{ Use } & \multicolumn{4}{c}{ Concentration } \\
\cline { 3 - 6 } & & F1 & F2 & F3 & NC \\
\hline Aloe vera Extract (\%) & Active substance & 1 & 3 & 5 & - \\
Karbopol 940 & Polymer & 2.25 & 2.25 & 2.25 & 2.25 \\
TEA & Buffer & 0.5 & 0.5 & 0.5 & 0.5 \\
Propilen glikol & Solubilizer & 5 & 5 & 5 & 5 \\
Metil Paraben & Preservative & 0.2 & 0.2 & 0.2 & 0.2 \\
Propil Paraben & Preservative & 0.1 & 0.1 & 0.1 & 0.1 \\
DMSO & Co-solvent & 7 & 7 & 7 & 7 \\
Aquadest & Solvent & Ad 100 & Ad 100 & Ad 100 & Ad 100 \\
\hline
\end{tabular}

\section{Evaluation of Aloe vera spray preparations Organoleptic examination}

Done to see the physical appearance of the preparation by observing the shape, color, and smell of the preparation that has been made (Depkes RI, 1995).

\section{Check the spray condition and weight per spray}

Spray preparations are sprayed from bottles 3,5 and $10 \mathrm{~cm}$ apart on a sheet of mica plastic. The test was carried out three times and observed the pattern of spray formation and weight per spray (Tiwari et al., 2011).

\section{Viscosity Measurement}

Viscosity of spray preparations was measured using Rion LV-04 viscester. Spray preparation as much as $75 \mathrm{~mL}$, put in a cup. Then the spindle no. 3, the viscosity results are recorded after the viskotester shows a stable number. Viscosity measurements carried out by replication three times. 


\section{Stickiness Check}

Testing the inherent resistance properties, the preparation was applied to the inner side of the volunteer's forearm, by spraying a spray gel at a distance of $3 \mathrm{~cm}$. When the spray drip drops after 10 seconds it is evaluated as dripping, and when the spray drip does not drip after 10 seconds it is evaluated as stickiness.

\section{pH measurement}

The $\mathrm{pH}$ is measured using a $\mathrm{pH}$ meter that has been calibrated from $\mathrm{pH} 4.01$ and $\mathrm{pH} 7.01$ (Depkes RI, 1995).

\section{Scattering checks}

The preparation is sprayed on mica plastic with a distance of $5 \mathrm{~cm}$. Then measure the spread of the preparation using a ruler. The parameters used are diameter.

\section{Dry time check}

Dry time testing, preparations were applied to the inside of the volunteers forearm. Then calculated the time needed until the sprayed liquid dries.

\section{Aloe vera extract wound spray healing activity test \\ Grouping of test animals}

15 mice were divided into 5 groups namely positive control using Oxoferin, negative control using base spray, treatment 1 was given spray extract of Aloe vera $1 \%$, treatment 2 was given spray spray of Aloe vera extract 3\%, treatment 3 was given spray extract of Aloe vera 5\%. The volume of treatment given was $5.3 \mathrm{mg}$ once a day for 13 days.

\section{Making full-thickness acute wounds}

Procedure for making acute-type full-thickness wounds by referring to research conducted by (Nasruddin et al., 2014) , mice were anesthetized before making wounds. The anesthesia was carried out with a mixture of Ketamine chemicals with a dose of $50 \mathrm{mg} / \mathrm{kg}$ bw and Xylazine dose of $5 \mathrm{mg} /$ $\mathrm{kg} \mathrm{bw}$ through the intraperitonial injection route. Then the hair on the mice's back is shaved using an animal shaver until it is smooth and the surface of the skin is visible. The wound was made on the back of male balb/c mice using a sterile disposable punch biopsy $4 \mathrm{~mm}$ in diameter on both sides of the circular dorsal (Nasruddin et al., 2014).

\section{Macroscopic observation}

Wound healing is evaluated macroscopically. The day of wound making is designated as day 0 and wound healing is observed every day from day 0 to day 14 after wound making. Before observation, the environment around the wound was cleaned using a $0.9 \%$ physiological $\mathrm{NaCl}$ solution. Documentation of wound images using a digital camera. The wound edges are imitated (traced) on plastic yashica using permanent markers every day. Wound area was calculated using Scion Image Beta 4.02 image analysis software (Scion Corporation, Frederick, Maryland, USA) (Wahyuningtyas and Putri, 2014). The result is a ratio of wound area from day 0 to 14 . The ratio of the wound area is calculated using the this formula:

$$
\text { Ratio of the wound area }=\frac{\text { area of the } \text { wound day } n}{\text { area of the wound day } 0}
$$

Then the data make into graphic with Origin 6.0. The inflammatory phase is indicated by the presence of a graph peak (Setyowati et al., 2019). 


\section{Data Analysis}

Analysis of the data used is the ratio of wound area to the skin of the entire treatment group. The data was analyzed statistically using IBM SPSS Statistics 20.0 software. All research data were carried out statistical prerequisite tests in the form of normality tests and homogeneity tests. The normality test is done with the Shapiro Wilk test, the data is said to be normally distributed if the significance value ( $p>0.05$ ). Next, a homogenity test was performed using the Levene's test, the data was said to be homogeneous if the value of $p>0.05$. If the data is normally distributed and homogeneous ( $p>0.05$ ), then the analysis of wound area ratio is continued with the one way Anova test. Data on the ratio of wound area is said to be a difference at each measurement time across groups if the $\mathrm{p}$ value $<0.05$, followed by the Tukey-Cramer Post Hoc test at a 95\% confidence level (Nasruddin et al., 2019).

\section{RESULTS AND DISCUSSION}

\section{Evaluation results of Aloe vera extract spray}

The spray preparations made vary the active ingredients into 3 series of concentrations, namely Aloe vera extract 1\%, 3\%, and 5\% dissolved with Dimethylsulfoxide (DMSO) which is well absorbed and also used as an enhancer in the process of absorption of drugs into the skin (Guerre and Casali, 1999). So that the spray can still flow, can adhere well, and to maintain the stability of the content in the preparation, carbohydrate is added. Carbopol has acidic properties, while skin $\mathrm{pH}$ is 4.5 6.5. Therefore, in the mixing triethanolamine (TEA) is added so that the spray is made according to the $\mathrm{pH}$ of the skin. In the formation of elastic film layers, propylenglycol is used as a plasticizer because it can work by giving free volume to the polymer which causes the polymer to have space to move so that the molecules in the polymer can have soft and flexible properties. Methyl parabens and propyl parabens are used as preservatives because these preparations are intended to heal open wounds so that they must be sterile and avoid microbial growth (Bergfeld et al., 2018).

Physical evaluation of Aloe vera extract spray was done after the three formulas are obtained, the evaluation results can be seen in Table 2.

Table 2. Physical evaluation results of Aloe vera extract spray

\begin{tabular}{lccc}
\hline Physical Evaluation & & Formula & \\
\cline { 2 - 4 } Results & F1 (1\%) & F2 (3\%) & F3 (5\%) \\
\hline Organoleptic & & & \\
1. Texture & Liquid & Liquid & Liquid \\
2. Odor & spesific extract & spesific extract & spesific extract \\
3. color & Dark green & Dark green & Dark green \\
Homogenity & Homogeneous & Homogeneous & Homogeneous \\
Viscosity & 0.6 dPas & 1.7 dPas & 1.8 dPas \\
pH & 6.56 & 6.04 & 5.03 \\
Scattering & $6.1 \mathrm{~cm}$ & $5.2 \mathrm{~cm}$ & $4.8 \mathrm{~cm}$ \\
Stickiness & cling & cling & cling \\
Spraying Pattern & & & \\
1. Distance $3 \mathrm{~cm}$ & Spread & Gather & Gather \\
2. Distance $5 \mathrm{~cm}$ & Spread & Gather & Gather \\
3. Distance $10 \mathrm{~cm}$ & Spread & Spread & Spread \\
Weight per spray & 5.33 & 5.66 & 5.66 \\
Dry Time & $58.26 \mathrm{~s}$ & $74.50 \mathrm{~s}$ & $96.30 \mathrm{~s}$ \\
\hline
\end{tabular}




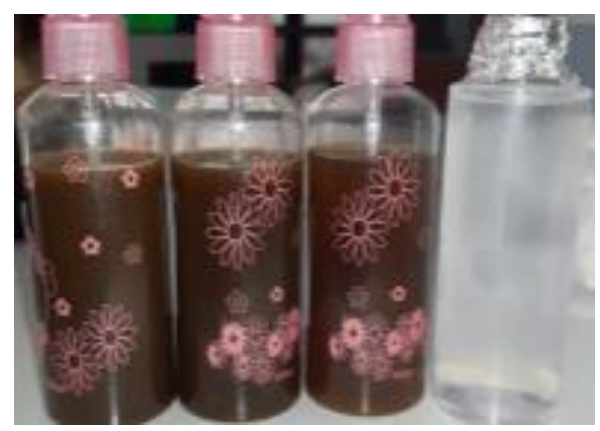

Figure 1. Aloe vera extract spray formulation results

\section{Wound healing activity test results of Aloe vera extract spray}

Wounds in the early days of the wound healing process in the inflammatory phase begin to expand until exudate appears and gradually the size of the wound begins to shrink until the end of the observation period (shown in Figure 2). The size of the wound in the spray group Aloe vera extract $1 \%, 3 \%, 5 \%$ from days 6 to 14 , smaller than the negative control group. On day 14 it appeared that the area of injury at the base was greater than all groups.

Figure. 3 shows the observed wounds on days $0,3,7,11$ and 14 for every group. The healing in all groups has a similar pattern, in which the wounds increased in size during the inflammation phase and then decreased gradually during the proliferative and maturation phases. The wound size on day 11 in the F3 group is smaller than that in the other groups. The yellowish color shown in the F1, F2, and F3 images consists of residue of the spray extract of Aloe vera.

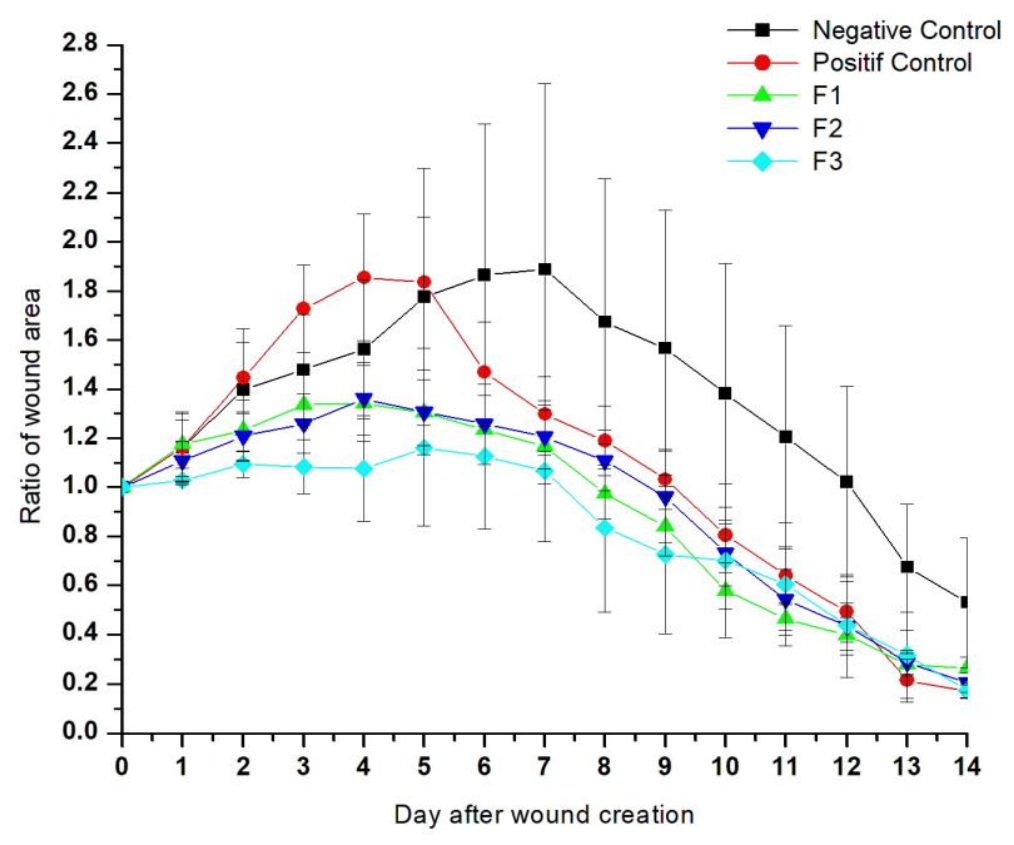

Figure 2. Extensive wound healing chart of Aloe vera extract spray 


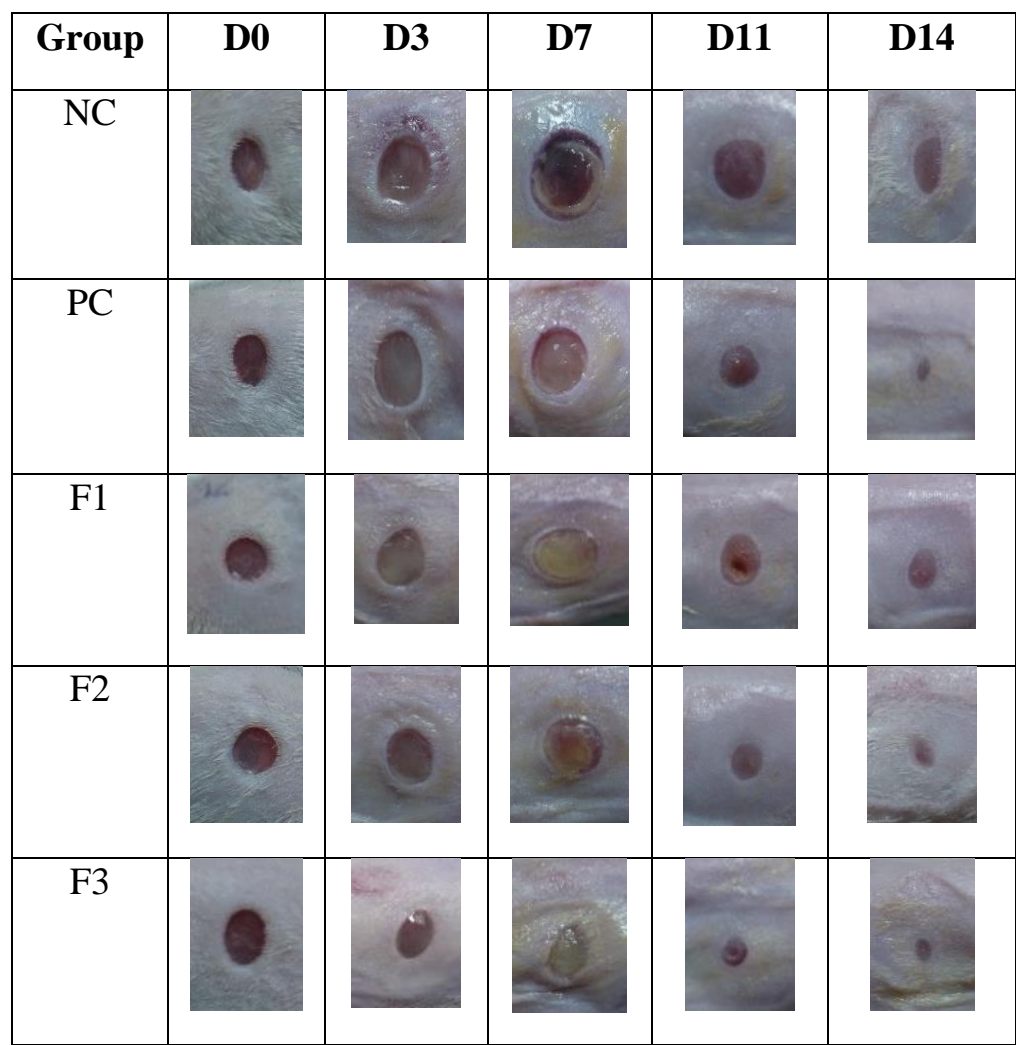

Figure 3. Macroscopically observed wounds on days $0,3,7,11$, and 14 with Aloe vera extract spray

The graph in Figure 2 shows the change in wound area during observation. The graph is the result of the calculation of the ratio of wound area on the day of observation to the area of the initial wound (day 0) from days 0 to 14 . Based on the graph it appears that all groups experienced a similar pattern of wound healing where for about the first 4 days, the wound experience an increase in wound area, then the wound has decreased gradually until the end of observation.

The treated groups, namely between groups F1, F2, and F3 can be seen in Figure 2 which shows that the F3 group experienced the lowest inflammatory phase and the highest remodeling phase from the macroscopy measurement has the smallest wound area, followed by F2, and F1 respectively, which can be seen in Figure 3. This shows that the higher of the concentration of Aloe vera extract, gave the better wound healing process. Wounded area of the three experimental groups (F1, F2, F3) experienced lower inflammation than the negative control (NC) and positive control (PC). Furthermore, on the 7th day the area of the wound of the experimental group that received spray treatment was almost comparable to PC and lower than NC. The area of injury in the PC group decreased more rapidly on days 7 to 14 .

The existence of wound healing activity is marked by a decrease in diameter. Based on the Post Hoc Tukey-Cramer analysis on the 14th day there were significant differences between the test groups $(\mathrm{F} 1, \mathrm{~F} 2, \mathrm{~F} 2)$ and positive control (KP) with negative control groups (NC) $(\mathrm{p}<0.05)$. From these data prove that Aloe vera extract spray has the ability to heal wounds and its ability is comparable to the synthetic drug Oxoferin.

The area of the wound in the treatment group (F1, F2, F3) was smaller than the negative control group where the area of the wound began to look smaller on the 8th day. The negative control group showed the highest inflammation. This can be caused there are no active substances that support the wound healing process, so that the wound has a longer healing phase. 
The results of wound healing activities in this study showed that spray extract of Aloe vera has the potential to heal wounds. This result has also been reported by (Takzare et al., 2009) on the study of influence of Aloe vera on dermal wound healing process in rats shows that the number of neutrophil, macrophage, and fibroblast cells and the wound thickness in the control group were statistically different from the experimental groups. It was found that the wound diameter thickness in the experimental group was greatly lower due to twice administration of gel and the power of wound healing was more than other groups (Takzare et al., 2009). Several other studies have also reported on biochemical studies that Aloe vera has revealed significant increase in collagen and decreased hexosamine content and malondialdehyde levels when compared with control (Yadav et al., 2012). The same thing is also shown by (Kayode, 2016) who has tested the effect of Aloe vera gel application on epidermal wound healing in the domestic rabbit. The results showed that animals treated with Aloe vera gel had significantly $(\mathrm{p}<0.05)$ faster rates of healing with shorter days of scab fall off than the control and showed significant $(\mathrm{P}<0.05)$ changes in the packed cell volume, mean corpuscular volume, lymphocyte and neutrophil counts (Kayode, 2016).

The possibility of wound healing activity is due to compounds that have anti-inflammatory activity contained in the Aloe vera extract. According to (Yagi and Takeo, 2003) Acemannan compounds contained in Aloe vera function as anti-inflammatory and are able to activate macrophages which will produce cytokines and growth factors that will stimulate fibroblasts, keratinocytes and endothelial cells for tissue repair. (Itrat, 2013; Yagi and Takeo, 2003). Polyvinylpyrrolidone (PVP) and gibberellins in Aloe vera can be used as antibacterial, stimulating the formation of fibroblasts and the formation of new tissue (Itrat, 2013; Sibbald et al., 2011). Other active substances contained in Aloe vera extract are vitamins and some amino acids, which can play an important role in accelerating wound healing in such a way that experiments have shown that vitamin $\mathrm{C}$ can play a role in increasing collagen production and preventing the synthesis of DNA strands. and vitamin $\mathrm{E}$ as a powerful antioxidant in wound healing (Itrat, 2013; Vázquez et al., 1996). These active substances can play a role in the process of healing acute wounds in male balb/c mice (Mus musculus) in this study.

\section{CONCLUSION}

Aloe vera extract spray has an acute wound healing activity on the skin of male balb/c mice and has an acute wound healing activity that is comparable to the synthetic drug Oxoferin ( $\mathrm{p}$-value>0.05). The best wound healing activity is the spray Aloe vera extract $5 \%$.

\section{ACKNOWLEDGEMENT}

This research was partly supported by the research grant PDUPT (Penelitian Dasar Unggulan Perguruan Tinggi), the Ministry of Research, Technology and Higher Education, the Republic of Indonesia (Number of contract : 004/16/AK/SP2H/PENELITIAN/2019)

\section{REFERENCES}

Bergfeld, V.;, Belsito, D., Hill, R., Klaassen, C., Liebler, D., Marks, J., Shank, R., Slaga, T., \& Snyder, P. (2018). Safety assessment of parabens as used in cosmetics. Cosmetic Ingredient Review, 128.

Depkes RI. (1995). Farmakope Indonesia Edisi IV.

Duansak, D., Somboonwong, J., \& Patumraj, S. (2003). Effects of Aloe vera on leukocyte adhesion and TNF- $\alpha$ and IL-6 levels in burn wounded rats. Clinical Hemorheology and Microcirculation, 29(3-4), 239-246.

Enoch, S., \& Leaper, D. J. (2007). Basic science of wound healing. Elsevier, 26(2).

Guerre, P., \& Casali, F. (1999). Dimethylsulfoxide ( DMSO ) : Experimental uses and toxicity. Revue de Médecine Vétérinaire, 150(5), 391-412.

Hashemi, S. A., Madani, S. A., \& Abediankenari, S. (2015). The review on properties of Aloe Vera in 
healing of cutaneous wounds. BioMed Research International, 2015.

Iswandana, R., \& Sihombing, L. K. (2017). Formulasi , uji stabilitas fisik , dan uji aktivitas secara In vitro sediaan spray antibau kaki yang mengandung ekstrak etanol daun sirih (Piper betle L .). Pharmaceutical Sciences and Research, 4(3), 121-131.

Itrat, M. (2013). Aloe vera : A review of its clinical effectiveness. International Research Journal of Pharmacy, 4(8), 75-79. https://doi.org/10.7897/2230-8407.04812

Kayode, O. A. (2016). Effects of aloe vera gel application on epidermal wound healing in the domestic rabbit. International Journal of Research in Medical Sciences, 5(1), 101. https://doi.org/10.18203/2320-6012.ijrms20164531

Menke, N. B., Ward, K. R., Witten, T. M., Bonchev, D. G., \& Diegelmann, R. F. (2007). Impaired wound healing. Clinics in Dermatology, 25(1), 19-25. https://doi.org/10.1016/j.clindermatol.2006.12.005

Nasruddin, N., Nakajima, Y., Mukai, K., Setyowati, H., Rahayu, E., \& Nur, M. (2014). Cold plasma on full-thickness cutaneous wound accelerates healing through promoting inflammation, reepithelialization and wound contraction. Clinical Plasma Medicine, 2, 28-35. https://doi.org/10.1016/j.cpme.2014.01.001

Nasruddin, N., Setyowati, H., Rahayu, E., Wahyuningtyas, E. S., Sikumbang, I. M., Nurani, L. H., Rohmani, A., Iswara, A., Salsabila, N., \& Setya, G. (2019). Efektivitas perlakuan irisan daun lidah buaya yang teraktivasi plasma jet untuk mempercepat penyembuhan luka akut fase proliferasi. Prosiding Seminar Nasional Unimus, 2, 18-25.

Setyowati, H., Rahayu, E., Nasruddin, N., Hayu, L., \& Darmawati, S. (2019). Ethanolic extract of the natural product of Daun sirih ( Piper betle ) leaves may impede the e ff ectiveness of the plasma jet contact style for acute wounds. Clinical Plasma Medicine, 15(18). https://doi.org/10.1016/j.cpme.2019.100090

Shahbaz, H. M., Manzoor, A., Ijaz, M., Mahmood, M. S., Mohy-ud-din, M. T., Gaad, A. H., \& Qamar, A. G. (2017). Comparative wound healing efficacy of neem oil, turmeric and Oxoferin ${ }^{\circledR}$ on full thickness cutaneous wounds in a rabbit model. 10(2), 66-71. https://doi.org/10.9790/23801002026671

Sibbald, R. G., Goodman, L., Halton, M., Woo, K. Y., Krasner, D. L., Tariq, G., Khalifa, S., Ayello, E. A., Burrell, R. E., Keast, D. H., Mayer, D., \& Norton, L. (2011). Special considerations in wound bed preparation 2011 : An update. Wound Care Journal, 24(September), 415-436.

Takzare, N., Hosseini, M., Hassanzadeh, G., \& Takzare, A. (2009). Influence of Aloe Vera gel on dermal wound healing process in rat toxicology mechanisms and methods influence of Aloe Vera gel on dermal wound healing process in rat. Toxicology Mechanisms and Methods, 19(April), 73-77. https://doi.org/10.1080/15376510802442444

Tiwari, P., Kumar, B., Kaur, M., Kaur, G., \& Kaur, H. (2011). Phytochemical screening and Extraction: A Review. Internationale Pharmaceutica Sciencia, 1(1).

Vázquez, B., Avila, G., Segura, D., \& Escalante, B. (1996). Antiinflammatory activity of extracts from Aloe vera gel. Journal of Ethnopharmacology, 55(1), 69-75. https://doi.org/10.1016/S03788741(96)01476-6

Wahyuningtyas, E. S., \& Putri, I. K. (2014). Efektivitas perlakuan kombinatif plasma medis , madu dan pembalut luka berlubang banyak untuk penyembuhan luka. University Research Colloquium, 2, 99-106.

Yadav, K., Ravi Kumar, J., Basha, S., \& Gujjula, R. (2012). Wound healing activity of topical application of Aloe Vera gel in experimental animal models. International Journal of Pharma and Bio Sciences, 3(2), 63-72.

Yagi, A., \& Takeo, S. (2003). Anti-inflammantory constituents, aloesin and aloemannan in Aloe species and effect of tanshinon VI in Salvia miltiorrhiza on heart. Yakugaku Zasshi, 123(7), 517532. 
